\title{
Peningkatan Kemampuan Pemecahan Masalah Matematis Siswa Kelas Vi Melalui Model Pembelajaran Kontekstual Pada Materi JAJARGENJANG
}

\author{
Vinna Triyana ${ }^{1)}$, Eka Murdani ${ }^{2)}$, Resy Nirawati ${ }^{3)}$ \\ 1) Program Studi Pendidikan Matematika, STKIP Singkawang, Indonesia \\ E-mail : riyanaramadhan2@gmail.com \\ 2) Program Studi Pendidikan Fisika, STKIP Singkawang, Indonesia \\ E-mail : ekamurdani@gmail.com \\ 3) Program Studi Pendidikan Matematika, STKIP Singkawang, Indonesia \\ E-mail : resynirawaty@gmail.com
}

\begin{abstract}
Abstrak. Penelitian ini bertujuan untuk menerapkan model pembelajaran kontekstual dalam rangka meningkatkan kemampuan pemecahan masalah matematis siswa. Penelitian ini dilaksanakan di SMP Asoka Singkawang Selatan. Bentuk penelitian yang digunakan Pre-Experimental Design dengan One Group Pretest-Postest Design. Populasi penelitian adalah semua siswa kelas VII. Sampel penelitian yang diambil menggunakan Sampling jenuh maka didapat kelas VII yang berjumlah 20 siswa sebagai kelas eksperimen. Untuk mendapatkan hasil penelitian digunakan tes kemampuan pemecahan masalah, dan lembar angket. Hasil penelitian ini menunjukkan model pembelajaran kontekstual telah dilaksanakan dengan memperoleh nilai rata-rata 65,95 terdapat peningkatan kemampuan pemecahan masalah matematis siswa melalui model pembelajaran kontekstual pada materi jajargenjang sebesar 0,43 yang berkriteria sedang. Ketuntasan siswa diperoleh sebesar $75 \%$ dengan jumlah siswa 20 orang, dan respon siswa menunjukkan kategori sangat baik dengan persentase $93,84 \%$. Dengan demikian secara keseluruhan dapat disimpulkan bahwa terdapat peningkatan kemampuan pemecahan masalah matematis melalui model pembelajaran kontekstual pada materi jajargenjang.
\end{abstract}

Kata kunci: model pembelajaran kontekstual, kemampuan pemecahan masalah, jajargenjang

\section{PENDAHULUAN}

Berdasarkan peraturan menteri pendidikan dan kebudayaan Nomor 59 tahun 2014 menyatakan bahwa mata pelajaran matematika perlu diberikan kepada seluruh peserta didik mulai sekolah dasar. Hal tersebut untuk membekali peserta didik dengan kemampuan berpikir logis, analitis, sistematis, kritis, inovatif dan kreatif, serta kemampuan bekerjasama. Permendiknas (2006) menuliskan tujuan mata pelajaran matematika untuk semua jenjang pendidikan dasar dan menengah adalah agar siswa mampu memecahkan masalah yang meliputi kemampuan memahami masalah, merancang model matematika, menyelesaikan model sesuai rencana, menafsirkan solusi yang diperoleh. Demikian pula tujuan yang diharapkan dalam pembelajaran matematika oleh National Council of Mathematics (NCTM) dalam lima standar pembelajaran matematika satu diantaranya yaitu kemampuan pemecahan masalah (problem solving) (NCTM, 2000). Melihat dari tujuan yang diharapkan oleh NCTM dan Depdiknas ini artinya kemampuan pemecahan masalah merupakan satu diantara kemampuan yang penting dikembangkan dan harus dimiliki oleh setiap siswa.

NCTM (2000) lebih lanjut menjelaskan bahwa pemecahan masalah merupakan bagian integral dalam pembelajaran matematika, sehingga hal tersebut tidak boleh dilepaskan dalam pembelajaran matematika. Namun pada kenyataanya, masih banyak siswa yang rendah dalam memecahkan masalah yang diberikan. Selain itu siswa juga mempunyai pandangan bahwa mata pelajaran matematika merupakan mata pelajaran yang sulit, membingungkan, dan tidak mengetahui cara menyelesaikan masalah matematika yang diberikan oleh guru khususnya pada materi jajargenjang.

Penyebab rendahnya kemampuan siswa dalam memecahkan masalah pada materi jajargenjang ini kebanyakan diawali dari lemahnya siswa dalam memahami 


\section{- - - Jurnal Pendidikan Matematika Indonesia \\ Volum 3 Nomor 1 bulan Maret 2018 Page 32 - 34 \\ p-ISSN: 2477-5967 e-ISSN: 2477-8443}

masalah yang ada. Kemudian lemahnya siswa menyusun perncanaan penyelesaian dan menyelesaikan masalah, dimana dalam hal ini berkaitan dengan kurang dilatihnya siswa untuk menyusun langkah-langkah penyelesaian serta lemahnya kemampuan siswa dalam menerapkan dan mengaitkan konsep-konsep jajargenjang yang telah dipelajari dengan kehidupan sehari-hari. Rendahnya kemampuan pemecahan masalah matematis juga didukung dengan banyaknya siswa kelas VII yang masih belum bisa menggunakan konsep serta menghubungkannya dalam kehidupan sehari-hari. Menurut guru matematika dinyatakan bahwa pada materi jajargenjang siswa cenderung memiliki kesulitan dalam menyelesaikan soal dikarenakan siswa belum memahami langkah-langkah dalam pemecahan masalah. Dan siswa yang tidak mengalami ketuntasan dalam materi jajargenjang mencapai 50\% dari kriteria ketuntasan minimal (KKM).

Selain itu peneliti juga melihat kurangnya respon siswa terhadapa pembelajaran matematika. Berdasarkan hasil observasi dan wawancara terhadap beberapa siswa, kurangnya respon ini ditandai dengan banyak siswa yang kurang memperhatikan dan member tanggapan terhadap pembelajaran yang berlangsung serta merasa bosan dan merasa pelajaran matematika itu sulit.

Melihat lemahnya kemampuan pemecahan masalah siswa, kurang aktifnya siswa dalam proses belajar mengajar dan kurangnya respon siswa dalam pembelajaran matematika, tentu diperlukan suatu tindakan yang tepat dan efektif untuk mengatasinya. Tindakan yang dapat dilakukan antara lain adalah menerapkan berbagai model pembelajaran yang sesuai dengan tujuan yang ingin dicapai. Oleh karena itu, peneliti menggunakan pembelajaran kontekstual sebagai solusi untuk menyelesaikan masalah yang diidentifikasi.

Menurut Suprijono (2013:79) pembelajaran kontekstual adalah konsep pembelajaran yang dapat membantu guru mengaitkan antara materi yang diajarkannya dengan situasi dunia nyata dan mendorong peserta didik membuat hubungan antara pengetahuan yang dimilikinya dengan penerapannya dalam kehidupan mereka sebagai anggota dan masyarakat. Pembelajaran kontekstual merupakan prosedur pendidikan yang bertujuan membantu peserta didik memahami makna bahan pelajaran yang mereka pelajari dengan cara menghubungkannya dengan konteks lingkungan mereka sendiri dalam lingkungan sosial dan budaya masyarakat.

\section{Metode Penelitian}

Jenis eksperimen yang dipakai dalam penelitian ini adalah pre-eksperimental design, dengan rancangan one group pretest and post-test design. Populasi dalam penelitian ini adalah siswa kelas VII SMP Asoka Singkawang Selatan. Di sekolah
Asoka hanya terdapat satu kelas VII, maka sampel dalam penelitian ini sama dengan populasinya, yaitu berjumlah 20 siswa, dengan demikian teknik pengambilan sampel yang digunakan dalam penelitian ini adalah sampling jenuh.

Teknik pengumpulan data yang digunakan dalam penelitian ini adalah (a) Teknik Pengukuran, yang berbentuk tes uraian (essay) yang terdiri dari 2 butir soal, (b) Teknik komunikasi tak langsung, dalam penelitian ini digunakan untuk mengetahui respon dalam belajar dengan perlakuan, dalam hal ini digunakan angket respon yang terdiri dari 13 pertanyaan berbentuk pilihan.

Untuk keperluan data dalam penelitian ini digunakan instrument yaitu (a) Tes kemampuan pemecahan masalah yang menggunakan tes tertulis berbentuk essay, (b) Lembar angket, angket dalam penelitian ini digunakan untuk memvalidasi suatu instrument dan untuk mengetahui respon siswa pada saat pembelajaran dengan model pembelajaran kontekstual berlangsung. Sebelum semua tes digunakan pada penelitian, maka terlebih dahulu instrument di uji cobakan ke sekolah lain yaitu SMP Torsina Singkawang untuk mengetahui kevaliditasan, reliabilitas, tingkat kesukaran, dan daya pembeda setiap butir soal.

\section{HASIL DAN PEMBAHASAN}

Hasil penelitian ini diperoleh dari beberapa data yang telah dianalisis. Adapun hasil yang diperoleh dari penelitian ini yaitu kemampuan pemecahan masalah matematis siswa, ketuntasan siswa dan pembelajaran menggunakan pembelajaran kontekstual, dan hasil angket respon siswa.

Berdasarkan hasil tes kemampuan pemecahan masalah matematis siswa diungkapkan bahwa nilai rata-rata hasil posttest lebih tinggi dibandingkan dengan nilai rata-rata hasil pretest. Nilai rata-rata hasil pre-test adalah 41,05 dan nilai ratarata hasil post-test adalah 65,95 . Hal ini menunjukan bahwa kemampuan pemecahan masalah matematis meningkat sebesar 24,9 setelah diberikan perlakuan dengan menggunakan model pembelajaran kontekstual.

Hasil pengolahan data tes akhir (posttest) kelas eksperimen menggunakan statistik deskriptif menunjukkan bahwa berdasarkan skor, diperoleh jumlah skor keseluruhan adalah 315 dengan rata-rata skor 15,75 skor tertinggi adalah 20 dan terendah 11. Sedangkan berdasarkan nilai diperoleh jumlah nilai keseluruhan adalah 1319 dengan rata-rata nilai 65,95 nilai tertinggi adalah 84 dan terendah 46 .

Hasil perhitungan yang memilih SS (Sangat Setuju) dan S (Setuju) sebesar 93,84\% dan yang memilih Kurang Setuju (KS), TS (Tidak Setuju), dan STS (Sangat Tidak Setuju) sebesar $6,15 \%$. Berdasarkan hasil perhitungan data tentang deskripsi respon siswa, maka diperoleh bahwa secara 
keseluruhan respon siswa positif belajar pada materi jajargenjang. Respon positif berarti siswa senang belajar dengan menggunakan pembelajaran kontekstual.

\section{SIMPULAN}

Kesimpulan dari penelitian ini adalah (1) Penerapan model pembelajaran kontekstual dapat meningkatkan kemampuan pemcahan masalah matematis pada materi jajargenjang, berdasarkan perhitungan $\mathrm{N}$-gain sebesar 0,43 (kategori sedang) dan Uji Hipotesis (Uji-t) bahwa t_hitung>t_tabel, $(9,3478>2,093)$ yang artinya H_a diterima dan H_o ditolak, (2) Ketuntasan hasil belajar siswa sebesar 75\%, dan (3) Respon siswa yang memilih Sangat Setuju (SS) dan Setuju (S) sebesar 93,84\% dan siswa yang memilih Kurang Setuju (KS), Tidak setuju (TS) dan Sangat Tidak Setuju (STS) 6,15\% sehingga dikatakan respon siswa tergolong positif.

Saran dari penelititan ini adalah (1) Model pembelajaran kontekstual sebaiknya diterapak dalam pembelajaran di sekolah, karena dapat memberikan peningkatan terhadap kemampuan pemecahan masalah matematis siswa, (2) Sebaiknya kemampuan pemecahan masalah siswa yang diajarkan dengan model pembelajaran kontekstual dapat diajarkan juga pada materi lain, dan (3) Sebaiknya ketika menggunakan model pembelajaran kontekstual ini, guru lebih membimbing siswa pada saat diskusi berlangsung agar siswa lebih bisa bekerja sama dan bertanggung jawab atas kelompoknya serta dapat memberikan semangat dan kepercayaan diri kepada siswa pada saat siswa akan mempresentasikan hasil kerjanya.

\section{UCAPAN TERIMA KASIH}

Ucapan terima kasih diberikan kepada STKIP Singkawang yang telah memfasilitasi penulis sehingga tulisan ini dapat dipublikasikan dalam berkala ilmiah STKIP Singkawang.

\section{DAFTAR PUSTAKA}

Heriawan, Adang, dkk. (2012). Metodologi Pembelajaran: Kajian Teoritis Praktis; Model, Pendekatan, Strategi, Metode, dan Teknik Pembelajaran. Serang-Banten: LP3G

Kemendikbud. (2013). Pendekatan dan Strategi Pembelajaran SD/SMP/SMA/SMK.

Kemendikbud. (2014). Peraturan Menteri Penddikan dan Kebudayaan Nomor 59 Tahun 2014 Tentang Kurikulum 2013 Sekolah Menengah Atas/Madrasah Aliyah.
Meliana Wenni. (2014). Respon dan Hasil Belajar Siswa Kelas IX MTs Muhammadiyah 1 Banjarmasin Terhadap Pemanfaatan Cd Pembelajaran Matematika. Prosiding. Banjarmasin. MTs Muhammadiyah 1 Banjarmasin

NCTM. (2000). Principle and Standards for Schoo Mathematics. Reston: United States of America.

Permendiknas. (2006). Peraturan Menteri Pendidikan Nasional Republik Indonesia Nomor 22 Tahub 2006 Tentang Standar Isi untuk Satuan Pendidikan Dasar dan Menengah.

Rajagukguk, Waminton. (2009). Upaua Meningkatkan Kemampuan Pemecahan Masalah Matematika dengan Penerapan Teori Bruner. Jurnal Nasional. Dairi.

Suprijono, Agus. (2013). Cooperatif Learning Teori dan Aplikasi PAIKEM, Yogyakarta: Pustaka Belajar. 